\title{
Preaching as art (imaging the unseen) and art as homiletics (verbalising the unseen): Towards the aesthetics of iconic thinking and poetic communication in homiletics
}

Author:
Daniel Louw',
Affiliations:
'Faculty of Theology,
University of Stellenbosch,
'Extraordinary professor,
North-West University,
Potchefstroom, South Africa
Corresponding author:
Daniel Louw,
djl@sun.ac.za
Dates:
Received: 26 July 2016
Accepted: 11 Oct. 2016
Published: 09 Dec. 2016
How to cite this article:
Louw, D.J., 2016, 'Preaching
as art (imaging the unseen)
and art as homiletics
(verbalising the unseen):
Towards the aesthetics of
iconic thinking and poetic
communication in homiletics',
HTS Teologiese Studies/
Theological Studies $72(2)$,
a3826. http://dx.doi.
org/10.4102/hts.v72i2.3826
Copyright:
Co 2016. The Authors.
Licensee: AOSIS. This work
is licensed under the
Creative Commons
Attribution License.

The article investigates the hypothesis that preaching implies more than merely verbalising, proclaiming and rhetoric reasoning. Preaching is fundamentally the art of poetic seeing; an aesthetic event on an ontic and spiritual level; that is, it provides vocabulary and images in order to help people to discover meaning in life (preaching as the art of foolishness). In this regard, preaching should provide God-images that open up the dimension of aesthetics and provide vistas of the 'unseen'. The iconic dimension of preaching is about symbols and metaphors that help people to 'see' in everyday life (a poetic gaze) the presence of God in such a way that tragic events, the awareness of death and the anguish about the fear for loss and rejection become events for signifying life and for healing (the quest for wholeness). It is argued that practical theology should be about a liturgy of life. In this regard, the 'ugliness of God' becomes an aesthetic category in a Christian spiritual approach to iconography. In order to do this a critical approach to praxis thinking should probe into the realm of paradigms, especially paradigms that describe the 'power of God'. Due to the assumption that the depiction of God's power was predominantly influenced by the Serapis, Zeus and Roman cult (Emperor mystique), a paradigm shift from omni-categories (pantokrator) to bowel categories (passio Dei) in the homiletic depiction of God is proposed.

\section{Introduction}

Preaching is a liturgical event which can take place on many different levels. It is a many-layered concept within a multidimensional approach:

- There is in the first place the kerygmatic dimension. This dimension is linked with the traditional understanding of preaching as proclamation and rhetoric reasoning. The gospel should be proclaimed, thus, the importance of exegesis and hermeneutics. Preaching often operates on the level of understanding and the cognitive. The emphasis is then on the rational and analytic capacity of both the preacher and the hearer: fides quaerens intellectum.

- Another dimension in the homiletic event is the emphasis on action and performance. Preaching as action within concrete, social contexts and cultural settings focuses on praxis and public issues. The emphasis is on change, transformation, liberation and societal reconstruction. Human acts of change function as vehicles for practical witness: fides quaerens actum. The latter wrestles with moral and ethical issues and put a lot of emphasis on motivation, thus, the dimension of the conative.

- However, there is also the deeper existential and ontological level of preaching: preaching as being-with and orientation within life events. It represents a kind of fellowship within the presence of God. It takes place in spaces of silence and contemplation and focuses on the symbolic and metaphoric meaning of different narratives and images in the Bible. One can call them the imaginative and iconic dimension of preaching: fides quaerens imaginem. This dimension focuses on habitus and attitude, namely the human ethos with its aim on human dignity and healing (wholeness). To discover the 'bigger picture of life' (the iconic and poetic gaze) is in itself a kind of existential sermon on divine presence; one is moved by the experience of awe - the affective dimension in experience and the ontic dimension of being (I am responsible and 'respond-able' - respondeo ergo sum).

The traditional approach in theory formation for homiletics is its emphasis on verbalising, rhetoric reasoning and the logic of speech. The preacher is fundamentally an orator and should entertain listeners with a clear, logical exposition and rational discourse. 
The practical theologian Wilhelm Gräb (2013) puts the emphasis on rhetoric reasoning in the homiletic event. In fact, in his publication on theory formation in homiletics (Predigtlehre), with the subtitle: Über religiöse Rede (religious reasoning), every chapter starts with the heading of Rede (reasoning). The biblical message should be proclaimed as blessing by means of a religious discourse and rhetoric reasoning (Gräb 2013:11).

Jan Hermelink and Alexander Deeg (2013) in their preface to the edition Viva Vox Evangelii - Reforming Preaching, state emphatically:

Viva Vox Evangelii: the living Word of the gospel is what Luther expected to be heard in sermons, hymns, and services. Of course, it is God's word and it is the Holy Spirit's transforming of the preacher's words into a living word that creates new faith. (p. 5)

The challenge for preachers therefore is to find words that bring biblical texts and the complex realities of today's world into conversation with one another.

But what about the endeavour of imaging the Biblical text by means of iconic imagination?

Thomas Long (1989:23) refers to the sermon as the core component of the event of preaching. 'It is an action, a spoken event, that the preacher performs in Christ's name'. Preaching thus enfolds and envelops as an event of audible wording. The preacher is thus: a herald, pastor, storyteller, witness of the gospel (Long 1989:23-47). The whole worship centralises around preaching as witness (Long 1989:47). Witness then means to behold and to attest. But witness implies more than testifying and proclaiming. According to Long (1989:78), witness is in the first sense 'to perceive'. And perceiving, to my mind, transcends the realm of merely hearing, verbalising and reasoning.

Perception leads in the first instance to seeing, imaging and imagining. And, in terms of a theology of preaching, it evolves around images of God. Preaching is in essence imaging God: the poetics of hopeful 'seeing', probing into the 'unseen' (Louw 2014).

Within the framework of homiletics as the aesthetics of seeing by means of both poetic speech and creative imaging, the preacher is becoming a kind of 'wise fool': preaching as the art of foolishness.

Campbell and Cilliers (2012:67-68), in their book on the art of preaching as the endeavour to distort the fixed conceptions in orthodox thinking, refer to Enid Welsford's notion that the art of foolishness implies an engagement of 'melting the solidity of the world'. Fools instigate and sustain liminality. 'They break into our circled wagons and smelt down our iron theologies'.

The fact is that we are moving into virtual reality with the emphasis on 'seeing' and symbolic thinking by means of imaginative experience. Should preachers not also try to find images that portray the vivid presence of a living God in order to open up vistas of hope? Thus, the challenge to also incorporate 'iconic seeing' in theory formation for preaching.

In this article I want to focus on fides quaerens imaginem: the iconic and aesthetic dimension of preaching as hopeful and faithful 'seeing'; preaching as deciphering of meaning and destiny of life by means of symbolising and imaging. The discovery of 'beauty' becomes an event in itself, a kind of homiletic happenstance; life is 'beautiful' and 'hopeful', hence, the emphasis on preaching as a deeply spiritual and iconic event.

Words and communication are attempts to transcend the immediacy of experience - its aim is to take human life further than merely the phenomenology of facts and observation of mundane entities. Its aim is to give language and vocabulary to life events and spiritual experiences. In this sense, meaningful communication is about the aesthetics of spirituality - the attempt to move experiences and objects into imaging and hope-giving visions. Words become 'chiffre' (Jaspers 1932, 1962), 'signals of transcendence' (Berger 1972): symbolic signs of the unseen. Signification in preaching then becomes 'Bauklötze, Signale, Wegweiser' (Steinmeyer 2011:264) for imaginative meaning creation. At the same time, words should take aesthetic awareness ${ }^{1}$ and observation seriously.

\section{Spiritual dimension of preaching}

Preaching as art should closely be connected to spirituality and the attempt to give form and expression to religious experiences. In a Study Guide, published by De Gruyter (De Gruyter Studienbuch 2009), Corinna Dahlgrün (2009:118-119) refers to the fact that spirituality is a multifaceted and manylayered concept with many meanings. However, one can construe the following communality despite the many definitions, namely that spirituality has to do with a transrational consideration and a sensitivity for transcendent awareness (the beyond and ultimate dimension of life) and shaping of impressions that supersede normal worldly experiences. $^{2}$

At a conference of clinicians, medical educators and chaplains for medical school courses on spirituality and health in 1999, the following clinical definition of spirituality had been agreed upon:

Spirituality is the aspect of humanity that refers to the way individuals seek and express meaning and purpose, and the way they experience their connectedness to the moment, to self, to nature and to the significant or sacred. (Puchalski \& Ferrell 2010:25)

1.Äestetisches Bewusstsein, auch und gerade im Angesicht von Werken der Kunst, ist ein Bewusstsein von Gegenwart - eine gegenüber der sonstigen Kenntnis des Hier und Jetzt gesteigerte Aufmerksamkeit für das Involviertsein in biographische und historische Zeit (Seel 2012:39).

2.'Unter Spiritualität wird stets etwas verstanden, das mit einem über- oder transrationaler Betrachten und gestalten des Lebens zu tun hat, der Begriff steht für eine Haltung, für ein Tun, für eine Lebensstil, die aus einem bestimmten, die Welt übersteigenden Sicht der Welt resultieren, aus einer Orientierung an dem "Einen" übersteigenden Sicht der Welt resultieren, aus einer Orientierung an dem "Einen" dabei handelt' (Dahlgrün 2009:121-122). 
Spirituality is for many people a way of engaging with the purpose and meaning of human existence and provides a reliable perspective on their lived experience and an orientation to the world. (Cobb, Puchalski \& Rumbold 2012:vii)

Thus, the conviction of Pellegrino (2012:vi) that healing of the psychosocial-biological is in itself insufficient to repair the existential disarray of the patient's life without recognition of the spiritual origins of that disarray. Besides the dimension of significance and purpose, 'spirituality can be understood as one's relationship to a transcendence that for some people might be God and for others might be different concepts of how they see themselves' (Puchalski \& Ferrell 2010:1-21).

Within the realm of suffering and human vulnerability, spirituality expresses the quest for human dignity. It thus represents a kind of caring and helping sensitivity and empathetic response that entails more than emotional involution; it represents an ethos of compassionate imagination.

\section{Preaching: Articulating and designating religious experiences}

Often the term 'spirituality' is used synonymously with 'religion' and has a binding and stabilising impact on people's attitude towards illness and suffering. "The word "religion" comes from the Latin term religare from re-again and ligareto bind. Thus, religions talk of spiritual experiences as the rebinding to God' (Puchalski \& Ferrell 2010:22).

Richard Schröder, in his book on the question whether religion should be abolished, (Abschaffung der Religion?) (2009:12-13) 3 points out that a world without religion does not guarantee heaven on earth. Current paradigms regarding the significance of religion refer to the fact that religion in one way or another is a given phenomenon and is intertwined with cultural and meaningful orientation (purposefulness) in life. Research in sociology of religion argues that the word religion stands for the dimension of norm-value and meaning-orientation. ${ }^{4}$ However, without religion, human existence runs the danger of losing its poetic gaze into guilt, sin, evil, ethic responsibility towards the 'ground of being' and an ethos of Eucharistic gratitude. The real danger lurks that we end up with an atheism of indifference (Atheismus der Gleichkültigkeit) (Schröder 2009:189).

3.See in this regard the challenging book by Ronald Dworkin: Religion without God (2013). Based on the 2011 Einstein Lectures, Religion without God is inspired by remarks Einstein made that if religion consists of awe towards mysteries which 'manifest themselves in the highest wisdom and the most radiant beauty, and which our dull faculties can comprehend only in the most primitive forms', then he, Einstein, was a religious person. 'Dworkin joins Einstein's sense of cosmic mystery and beauty to the claim that value is objective, independent of mind, and immanent in the world. He rejects the metaphysics of naturalism - that nothing is real except what can be studied by the natural sciences. Belief in God is one manifestation of this deeper worldview, but not the only one. The conviction that God underwrites value presupposes a prior commitment to the independent reality of that value - a commitment that is available to nonbelievers as well. So theists share a commitment with some atheists that is more fundamental than theists share a commitment with some atheists that is more fundamental than what divides them. Freedom of religion should flow not from a respect for belief in God but from the right to ethical independence'. On line: http://www.hup.harvard.
edu/catalog.php?isbn=9780674726826. Accessed: 08/03/2016.

4.'Das Wort steht dann für die Dimension von Norm-, Wert- und Sinnorientierung. Nach diesem Religionsbegriff kann man sinnvol auch von einer atheistischen Religion sprechen' (Schröder 2009:93).
In essence, preaching probes into the realm of spirituality and gives form to religious experiences; it is an attempt to bring about integration in life and instil a form of hope that brings about significance and meaning. In this respect, the poetic gaze and artistic expressions help to shape and create aesthetic modes of seeing and hearing differently; namely 'seeing the unseen'.

\section{The art of seeing more: A poetic gaze}

John Berger, in his book Ways of seeing (1972:7), makes the profound statement: 'Seeing comes before words. The child looks and recognizes before it can speak'. Even before one articulates and translates our surrounding world, seeing establishes our place in space. This is the reason why seeing precedes verbalising and imaging.

According to Berger (1972:7-10), an image is a sight which has been recreated or reproduced. It refers to an appearance or set of appearances, which have been detached from the place and time in which it first made its appearance. For example, in painting, the painter's way of seeing is reconstructed by the marks they make on the canvas or paper. Yet, although every image embodies a way of seeing, supported by a mode of inspiration and a creative act of imagination, our perceptions or appreciation of an image depends on our own way of seeing, on the poetic gaze and aesthetic perception that shape the appearances of something that was absent but has become visible or audible. Due to seeing, even the image could outlast what it represented (Berger 1972:10).

In 1992 Ellen Dissanyake wrote a book entitled Homo aestheticus: Where art comes from and why. ${ }^{5}$ Her basic assumption is that art can be regarded as a natural general proclivity that manifests itself in culturally learned specifics such as dances, songs, performances, visual display and poetic speech. Art makes life special, because the endeavour of art involves taking something out of its everyday and ordinary use context and making it somehow special - the ordinary becomes extraordinary.

Within the computer business and the pragmatic demands posed by man as homo faber (man as a producer of things; the making human being), Steve Jobs saw more. Jobs toyed with the 'idea of beauty' (homo aestheticus: man as the creator of beauty).

Steve Jobs combined his slogan 'Let's make a dent in the universe' (Blumenthal 2012:93) with the aesthetics and art of design. While his youth companion Steve Wozniak could see 'a sonnet in a circuit', Jobs, by contrast, could look at a beige box and see beauty (Blumenthal 2012:80). 'He imagined a computer that was graceful and elegant as it was useful, an intersection of technology and art that resulted in something truly special' (Blumenthal 2012:80). Steve Jobs changes a

5.Ernst Billgren (2011:13) responds to the question What is art? as follows: "Just as a physicist is a collection of atoms trying to discern what an atom is, so art is an invention that aims to discover what art is'. 
possible bankrupt company, Apple, into a financial miracle. The secret? He stayed true to his original vision for Apple: He believed there was room for beauty and art amid technology and commerce (Blumenthal 2012:198).

Imaging is to 'see' more. An iconic view probes into the 'idea' within and behind the object. In imaging, imagination starts to guess, to suspect some-thing more; imaging toys with probability and creates something different, something that supersedes the senses. True imaging does what the Italians call 'sfumato' - 'the blurred outline and mellowed colours that allow one form to merge with another and always leave something to our imagination' (Gombrich 2006:228).

Imaging mystifies. This is the reason why, for example, artists in Japanese culture and art have always tried to merge seeing with glimpses of not-seeing. In Japanese gardens nature becomes a medium for reflection on divine presence, and the elements of nature a 'second eye' into transcendence. The gardens function as settings for meditation, the goal of which is spiritual enlightenment. The classic example is the karesansui (dry landscape) consisting of meticulously placed rocks and raked gravel.

The rock garden at Ryōan-ji (Kyōto, Japan) is a classic example. There are various interpretations of the symbolic significance of the gardens (Young \& Young 2005:109). The rock groupings surrounded by white sand have been described as representing islands in the sea, mountains rising above the clouds or a mother tiger and cubs crossing a river.

Regardless of what the creators originally have had in mind, the garden, like a Zen black ink painting, is a meditative device that encourages those sitting on the deck to participate in the creative act and provide their own interpretations. Some Zen priests contend that by intense meditation one may be transported into the garden, which, despite its small size, represents infinity - a place beyond time and space where it is possible to experience the pure potentiality that is the source of all existence. (Young \& Young 2005:109)

Aesthetic observations and experiences make the presence, present (Vergenwärtigung der Gegenwart, Seel 2012:37). It represents experiences of transcending factuality and phenomenology, not to conquer time and to ignore the fact that our existence is encapsulated by time (temporality of life), but to intensify experiences in time and place (Seel 2012:39). ${ }^{6}$

One can even argue that the spirituality of aesthetics contributes to a widening of a horizon that opens up new perspectives on the sacred dimension of life. It even opens up spaces and different (new) relations with the divine; it penetrates the realm of the incomprehensible and nondisposable. It also discloses indicators that can guide human beings in their search for meaning ${ }^{7}$ and quest for resilience,

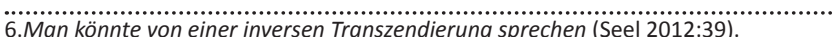

7.See Gräb 2012:53-67; art creates new spaces and changes spaces and leads to '... einer Sinn erschliessenden Erfahrung erweitern' (Gräb 2012:53) (art as a kind of extension - 'verruiming'). strength and trust. Aesthetics and arts create images for human self-transcendence and freedom ${ }^{8}$; it can be called the epiphany of poetic hearing and artistic seeing; it probes into the beyond and the realm of the ultimate. In fact, art and poetic seeing 'save' human beings from deadly helplessness (Willikens in Willikens \& Schüz 2012:265).

Aesthetic experiences in religion contributes to a kind of self-critique (Seel 2012:45) due to the fact that it creates transcending experiences that help one to find distance and help religious reflection to become free from fixation and the nurturing of zombie categories, i.e. traditional categories that have become inappropriate to translate the awareness of divine presence within historical and cultural contexts.

It is indeed a fact that in modern culture art has been excluded from church life. However, it does not mean that art does not represent a religious and spiritual dimension (Gräb 2007:738). Aesthetic signs should thus be viewed as part of practical theological reflection (Gräb 2007:737). Symbolisation and aesthetic signification are integral ingredients of Christian reflection on meaningful perspectives for life and significant religious experiences of divine presence. Art and religion should thus be viewed as asymmetric bipolarities (Gräb 2007:738) in processes of religious interpretation and signification.

It was the conviction of the English producer Peter Brook that meaningful images change the life of human beings, thus, the need for theatre. On stage an image creates experience and makes impressions real (an event). Images become signs, tracks in the mind (in Steinmeyer 2011:268). In terms of the philosopher K. Jaspers: chiffré $(1932,1962)$, to be signified in order to trace down human attempts to signify life. This is why Steinmeyer wants to talk about the eyes of wording and language ('Auge der Sprache', Steinmeyer 2011:255). Words make seeing possible, while arts make seeing invisible (poetic seeing): that is seeing the unseen. Thus, the question of whether preaching should only compile and arrange fixed ideas (Steinmeyer 2011:261) (dogmatic fixation) (service to zombie categories), or try to link spiritual reflection creatively and imaginatively to worldly events.

What is then meant by the aesthetic dimension in preaching?

\section{Preaching: The charm of practical theological aesthetics}

Preaching is, as a public-homiletic reflection, in essence a contextual, cultural and civil event, (Steinmeyer 2011:254). Thus, the challenging question is: how should theological reflection in homiletics respond to vital issues in society?

Response to difficult life situations is often difficult because there are no prescribed texts with immediate, instant answers.

8.'Die religiöse Transzendenz der Kunststellt somit einen Modus der Realisierung einer Grundform der menschlicher Selbsttranszendierung dar' (Seel 2012:47); the einer Grundform der menschlicher Selbsttranszendierung dar' (Seel 2012:47); the
religious charm of art can be called a kind the epiphany of artistic thinking and religious 
What is most needed in preaching is creativity and imagination in order to probe into new or different options. Is it therefore possible to incorporate imagination, imaging and poetic and artistic reflection in a practical theological approach to homiletics despite the fact that there is still a kind of sceptic reservation about imaging in theologising? ${ }^{9}$ And hence is the thesis of Hoeps (2012:92) that art should be 'charming' (attractive option) for doing theology in praxis.

The advantage of the religious charm of art ('religiöse Charme der Kunst', Hoeps 2012:91-94), and imaging in a practical theological aesthetics, is the following:

1. Images in art provide a complex network of translation and hermeneutic interpretation that exceeds the limitations of the audible and the vocal.

2. Images in the Christian faith help to take part in the incommensurable playfulness of human expressions and acknowledgements within creative divine reflections on the presence of God in this world. Images create a unique constellation of metaphorical speech ${ }^{10}$; it is about a kind of mysterious mirroring ('rätselhafte Spiegelbilder', Hoeps 2012:940).

3. The metaphoric nature of images assists human beings to acknowledge transcendent experiences and create a kind of spiritual well-being that leads to motivation and initiative.

Homiletics as an act of communication is about a practical theological act of communicative engagement with life (Grethlein 2012:v). In this respect, art helps the human mind to experience and imagine new and different perspectives. Due to contingency one has to toy with several options (Steinmeyer 2011:254). In this respect the flexibility of poetic and iconic thinking in a practical theological aesthetics can be most helpful.

The point is: art can open up new and different perspectives and spaces that the senses cannot 'see' and detect.

- By means of symbolisation, the hermeneutics of art probes into the mystery of life; it is a spiritual act of transcending the facticity of human direct and observed experience, superseding the mundane by means of an awareness of the sublime.

- Preaching creates culture (colo = to care and to transform reality into a second cosmos) ${ }^{11}$ and brings about the unseen into existence.

- As a cultural event, preaching acts as a liturgy of life; it shapes life according to a creative event of iconic thinking and poetic seeing.

9.... weil der Theologie oft selbst unschlüssig ist, was sie - zumindesten in ihren systematischen Diskursen - mit Imaginationen, mit Phänomenen des Bildlichen und mit künstlerischen Reflexionen anfangen soll' (Hoeps 2012:91).

10.'Zwar in anderer Weise als Texte operieren doch auch Bilder mit einer Art von Metaphorik, von der alle Rede über Gott geprägt ist, in einer Anschauung zu, in der die Evidenz der Sichtbarkeit mit der Ungründlichkeit des Scheins verschränkt ist' (Hoeps 2012:91).

11.'Predigt ist ein kreatives Gespräch, in dem wir, wie mit Bewegungen eines pflugs, miteienander Linien schaffen' (Steinmeyer 2011:267).
The argument thus far is that the focal issue on the agenda of preaching is life. Preaching should thus promote the healing of life and the fostering of a culture of human dignity. The further implication is that homiletics, as a mode of doing theology in practical theology, is in essence an aesthetic event.

\section{The homiletics of singing: Towards a liturgy of life}

It is often argued that practical theology $y^{12}$ is about analysing and reflecting the communication of the gospel within the present realms of life (Grethlein 2012:v). Instead of 'zombie categories' (categories that represent a historic context that is not any more appropriate for recent cultural contexts), practical theology should be transformed as the theory of communicating the gospel in terms of existential life issues (Grethlein 2012:143-192). In this regard, the concept 'life ${ }^{\prime 13}$ is emerging more and more as a theme in practical theological reflection. Together with religious experiences and spiritual awareness (transcendent experiences ${ }^{14}$ ) (Lauster 2007:143), the interplay between life and meaning has become an important ingredient of practical theological reflection on divine presence within the existential dynamics of daily life events.

Communication implies inter alia helping people on how to live and to cope with the demands of daily living (Helfen zum Leben) ${ }^{15}$ (Grethlein 2012:166), thus, the reason why hope features time and again as eventual framework for meaningful living. Hope represents the spiritual notion that life is about more than merely human achievements. Life includes the experience of 'the ultimate' - 'Jenseits' as driving force in our 'Diesseits'. Life is the striving towards a kind of fulfilment that connects sustainability with eternal images - 'Mehrwert des Lebens' (Lauster 2007:146-147).

Furthermore, life is becoming a kind of keystone concept in order to describe the praxis implications of theology in contemporary society. In an introductory article on the edition of practical theology as a kind of life science, Martina Kumlehn (2011:4) argues for practical theology as a kind of life science (Lebenswisssenschaft Praktische Theologie?!) The argument is more or less the same as my conviction that practical theology and caregiving are in essence engaged in life events with the view of healing and wholeness: cura animarum as cura vitae (Louw 2008) and should thus be seen as faith-seeking, meaningful lifestyles (fides quaerens vivendi).

12.'Praktische Theologie analysiert und reflektiert die Kommunikation des Evangeliums in der Gegenwart' (Grethlein 2012:v).

13.In this regard, the link between the human spirit (Geist) and the quest for meaning and care (Sorge) becomes important topics in practical theological reflection (Lauster 2007:142-143). 'Es ist eine Grundeinsicht theologischer und philosophischer Überlegungen zum Lebensbegriff, den Geist als jene Dimension zu begreifen, in dem das Leben selbst zum Bewusstsein gelangt' (Lauster 2007:142); 'Die Sorge um das eigene Leben ist darum ein pimrärer Ort für die Erfahrung von Transzendenz' (Lauster 2007:143).

14.The notion of transcendence points to the invisible realm of meaning, religious experiences and awareness of a kind of ultimate destiny that supersedes merely observational experiences. Due to the Internet and the media, transcendent experiences have become popularised ('Die Transzendenzerfahrung wird popularisiert') (Grethlein 2012:177).

15.'Da sie Menschen zu einem neuen Alltag befreite, aber zugleich eschatologisch ausgerichtet war, nenne ich diese Kommunikationsform Helfen zum Leben' (Grethlein 2012:167) 
Life then as a qualitative and relational category implies the systemic interplay between natural or cosmic forces, biological and physiological factors, structural and technological infrastructure; existential challenges as embedded in the trajectories of daily life; spiritual matters as related to the ultimate realm of life, as well as religious experiences. In this regard, life should be viewed as a networking category including the notion of transcendence and the human quest for meaning (significance) and dignity within the framework of values, belief systems, moral questions, convictions and philosophical constructions.

Kumlehn (2011:40) refers to practical theology as a science that should give attention to promoting a kind of 'religion of life' (Religion des Lebens). The presupposition is that there exists a close connection between life and religious experiences. Practical theology should, thus, be engaged in life issues; it should try to enhance the quality of life and focuses constantly on human well-being, health and healing (Heil). With reference to Pierre Bühler (in Kumlehn 2011:5), the challenge is how to understand life and create a hermeneutics of life in close connection (symbiosis) with the natural sciences, health sciences and technology.

According to (Korsch 2011:342) ${ }^{16}$ life as an object of practical theological reflection implies a metaphoric understanding (hermeneutics) of daily life events in order to open up new future options for human self-realisation and meaningful hope.

Homiletics as a sub-discipline in practical theology articulates life within the dynamics of the encounter between God and human beings. This covenantal relationship is in the first place an aesthetic event (the indicative of God's incarnational engagement in life). The imperative emanates from this indicative of grace and redemption. Aesthetic preaching can thus be called the art of gossiping the gospel within the rhythm of daily living. It deals with the hallelujah of ecstatic celebration.

We can start singing like Louis Armstrong: $O$, what a wonderful world! But this singing and ecstatic exclamation are not about a kind of spiritual escapism, ignorance, denial or artificial withdrawal. It is deeply being aware of the existential reality of pain, suffering, tragedy and death.

Singing in liturgy within a homiletics of life should always start with lament because suffering is an unavoidable ingredient of life, thus my basic assumption and presupposition that in a practical theological aesthetics, the poetics of preaching should emphasise a pathetic paradigm rather than an imperialistic pantokrator paradigm.

In order to link a practical, theological aesthetics, spiritual reflection and a poetic gaze to real-life events, preaching has

\footnotetext{
16.The basic thesis of Korsch (2011:342) is that life is about self-fulfilment; Leben ist Selbststeigerung. 'diese verfasstheit des Lebens betrifft sowohl die materiellen Erscheinungsformen organismischer Art - als auch die Metaphorik, die den Lebensbegriff so universal anwendbar macht für zukunftsoffene Selbstorganisationsprozesse' (Korsch 2011:342).
}

to become aware of its own paradigms (conceptualisation and patterns of thinking). Paradigms in religious seeing are linked to concepts and specific ideas about life, the world and the divine. It is in this regard that the visual arts can help to unmask the idea and concept behind the words because aesthetics includes the art of appropriate conceptualisation. New approaches to theory formation in art emphasise more and more the fact that art is conceptual; art can only exist due to concepts (Rebentisch 2013:136). According to the artist Duchamp (in Rebentisch 2013:137), art wants to express propositions that exceed the impact of the image or work of art. The proposition connects form and matter and reflects the foundational idea or concept of artistic seeing. ${ }^{17}$ Aesthetics thus becomes the dynamic interplay between form and content, matter and significance (Rebentisch 2013:139).

Due to the factor of proposition and idea, one can trace down how, for example, Hellenistic conceptualisations and ideas about power and divine ontology influenced Christian religious art and images about the omnipotence and being of God Almighty. To my mind, Greek philosophy and Egyptian mythology determined propositions and dogmatic conceptualisation that often lead to a very static ecclesiology and ritualisation that reflect more the immutability of a Caesar-like God than a pathetic, compassionate God. We preached an Atlas figure rather than a Wounded Healer (Nouwen 1979).

One could thus argue that preaching as art and arts as homiletics have inter alia the task to revisit the paradigmatic background and idea-matic framework of religious thinking and conceptualisation. One such idea-matic framework can be called the Emperor mystique in imperialistic thinking and clerical preaching. In clerical preaching the intention was most of times to maintain ecclesial power and to uphold the image of authoritative clergy (the office) and official church polity (synodic decisions and confessional doctrine), rather than the plight of suffering human beings in their quest for justice and dignity.

\section{Probing the imagery of God: The theory of the 'Emperor Mystique' in iconic thinking}

It is quite generally accepted that the Roman and Hellenistic paradigms of imperialistic thinking had a huge impact on conceptualisation in Christian reflection. Very specifically how the notion of God Almighty has been translated, preached and conceptualised in many writings of the church. An example is how God is still portrayed in terms of static categories and power images that are nearer to Greek and Roman thinking than to Jewish thinking.

In theology God's omnipotence has often been interpreted not in soteriological and sacrificial terms, but in Hellenistic

17.'Ganz Analog soll es in der Kunst nach Duchamp, glaubt man Kosuth, ebenfalls nicht um diese spezifische material Gestaltung gehen, veilmehr sei diese genüber
der Proposition, der jeweiligen Idee von Kunst also, um dies es eigentlich gehe, beliebig' (Rebentisch 2013:137). 
terms: pantokrator. The latter is the Greek version of the Hebrew phrase 'el Saddaj (Hieronymus used the Latin version deus omnipotens). It is a fact that God revealed himself several times as the Almighty. Genesis 17:1: 'the Lord appeared to him [Abraham] and said 'I am God Almighty' (see Gn 28:3, 35:11, 43:14, 49:25; Ex 6:3).

The interpretation of pantokrator in terms of imperialistic and omni-categories to main divine control and predestination categories functions strongly in the theodicy question. It also determines our thinking regarding creation and healing, even the core of confessional faith, hence the concern of Käfer (2015:89-112) to revisit the way in which the Heidelberg Confession refers to the almighty power of God.

Theodicy (theos = God, dike = justice; can one justify God, the ways of God, in the light of the possible inexplicable existence of evil?), strictly conceived, is the philosophical attempt to show that Christians can believe simultaneously and with logical consistency: 'God is omnipotent and omnibenevolent and evil is real; God is omnipotent and can do all'.

In doctrine, the notion of permission (permettre) is often introduced to project a kind of divine fitness. However, the danger lurks that this powerful God can become too strong for human vulnerability. At the same time, theologians try to 'save' God by emphasising that suffering and evil are not the will of God. Another problem then surfaces: God becomes too weak for coping with our human predicament, a kind of divine fatigue (the depleted God). Both divine fitness and divine fatigue cast a shadow over compassion and a praxis of hope.

Formulated in simple syllogism (Inbody 1997) the logical problem can be stated in this syllogistic form:

If God is omnipotent, He could prevent all evil.

If God were perfectly good, He would want to prevent all evil.

There is evil.

Therefore, (an omnipotent, perfectly good) God does not exist. (p. 28)

According to Van de Beek (1984:91-92), behind the concept 'omnipotence' lies the motive to see God as the absolute One, the Super King with a driving force (despotes). Behind every event God functions as the prima causa. ${ }^{18}$ Van de Beek is convinced that more fundamental than Berkhofs 'weerloze overmacht' (Berkhof 1973) is the overwhelming phenomenon of God's majestic highness and splendid glory. God's dominion and sovereignty exist in the interest of humankind; his aim is to conquer the evil powers of sin and darkness.

It is against this background that one should understand the emphasis on the suffering of Christ and God in theopaschitic

18.Van de Beek (1984.91-92) concludes that it is very difficult to eliminate the concept 'omnipotence'. The Almighty God is, indeed, a biblical concept. The only problem is that God's dominion and sovereignty have been misused by many people. Therefore, it is difficult to correlate his dominion with the suffering and injustice in history. theology. See for example Moltmann's theology of hope in suffering: God's suffering as a theologia crucis. ${ }^{19}$

The suffering God and the theology of the cross constitute the framework for a new paradigm, ${ }^{20}$ i.e. God's omnipotent presence and power interpreted as vulnerable faithfulness and overwhelming pathos. Although this sounds new, the roots can be traced back to Martin Luther's well-known thesis: 'The man who perceives the visible rearward parts of God as seen in suffering and the cross does however deserve to be called a theologian'. For Luther, the cross indeed reveals God - but that revelation is the posteriora Dei. The important thing about Luther's assertion is that the cross of Christ, in which God is found to be revealed and yet paradoxically hidden in that revelation, becomes the sole authentic locus of the human knowledge of God. The implication of this thesis is that God's strength (omnipotence) is revealed in apparent weakness, and his wisdom in folly.

Michael Schafer, in the edition of Geo Epoche: Die Kunst der Antike (2014:1), points out that Christian art, especially in the middle ages, was dominated by static Hellenistic paradigms that tried to glorify God in terms of an aesthetics of faith'. However, the divine images did not make space for human beings within their vulnerability and predicament of suffering.

One theory in the interpretation of early Christian iconography is called the theory of the 'Emperor Mystique' (Mathews 1993:12).

The 'Emperor Mystique' approach refers to the theory in iconography accepted by art historians, namely that the images of Christ in Early Christian imagery were derived from images of the Roman emperor:

Both the shape and the power of the images, according to this theory, come from reliance on imagery formerly used to present the emperor. I call this approach the 'Emperor Mystique'. It is a 'mystique' in so far as it involves a reverence bordering on cult for everything belonging to the emperor. To such historians dropping the word 'imperial' into a discussion represents an appeal to a kind of ultimate value beyond which one never look. (Mathews 1993:12)

The Hellenistic and Roman background of icons should be acknowledged (Nyssen 1982:413). It is quite understandable that in their search for identity, the followers of Christ in the Roman era expressed their identities in terms and images that draw on widely shared cultural categories. The similarities are evident. However, Christians indeed reinterpreted such categories in a different and unique way. According to Harland (2009:47), the letters of Ignatius of Antioch, which reflect group life in two central hubs of early Christianity - Western Asia Minor and Syrian Antioch -

19.Moltmann (1972:180): 'Das Leiden und Sterben Jesu, verstanden als Leiden und Sterben des Gottessohnes, aber sind Werke Gottes gegenuber sich selbst und Sterben des Gottessohnes, aber

20.Inbody (1997:9): 'Although there are differences among trinitarian theologians, they all imply that the power of God is to be defined by the cross and the resurrection not by the omnipotence of theism'. 

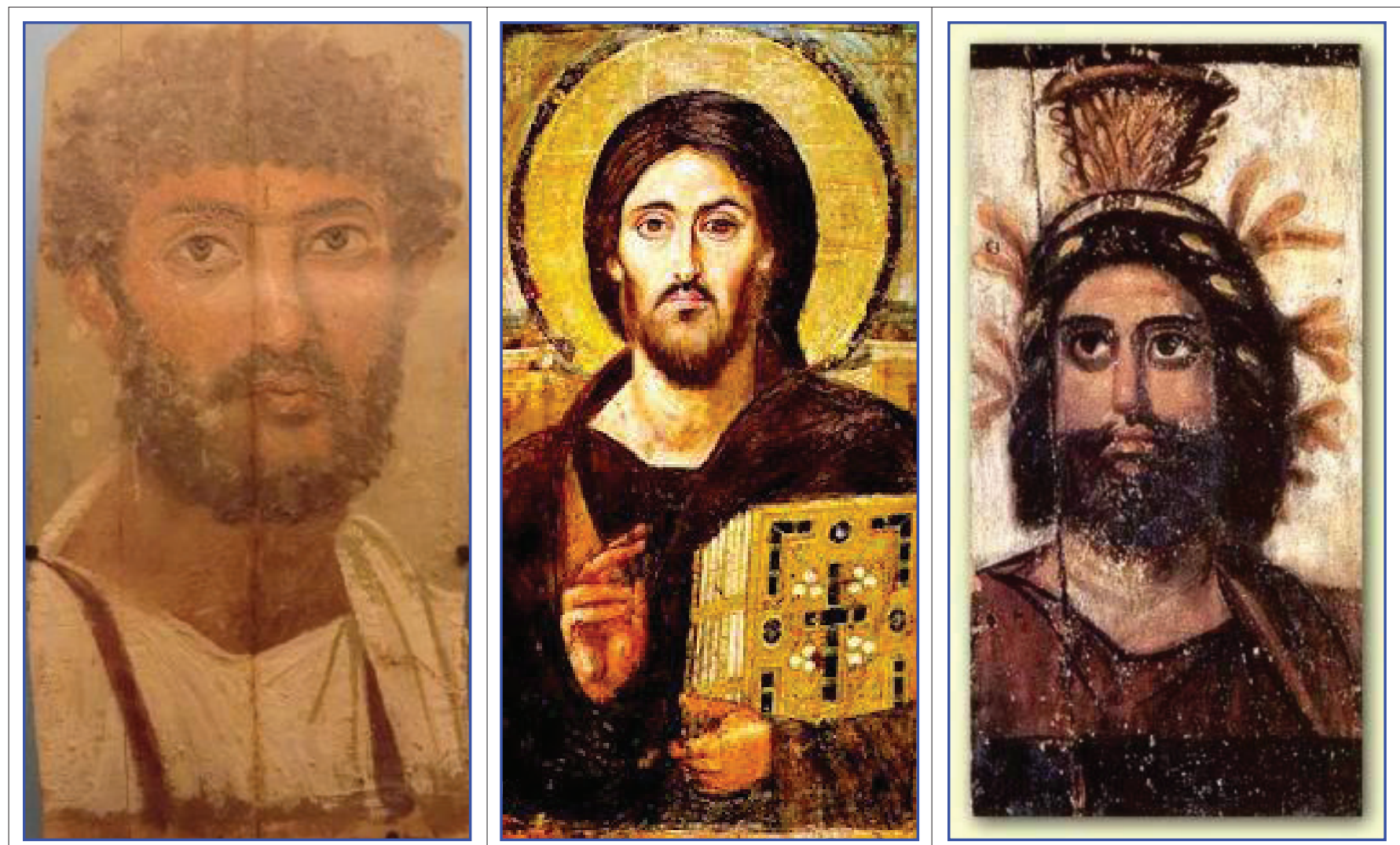

The possible similarity between the depiction of Serapis (A Greco-Egyptian god BC: left panel) and the oldest icon of Christ Pantokrator on a panel (right) from the Saint Catherine Monastery near Mount Sinai, was obvious to many. The two different facial expressions on either side may emphasize Christ's two natures as fully God and fully human. (Free image: http://en. wikipedia org/wiki/ Christ Pan, was obvous to many. The two different facial expressions on either side may emphasize Christ's two natures as fully God and fully human. (Free image: http://en.wikipedia.org/wiki/ mixed with egg. Circa 110 AD. (Permission: National Museum Copenhagen. Photo: D. J. Louw). In ancient portraiture general images were often used to depict faces. Thus the resemblance with mixed with egg. Circa 110 AD. (Permission: National Muse

FIGURE 1: Serapis, a Greco-Egyptian god BC.

provide a case in point. In these writings Ignatius drew heavily on categories from the culture of Greco-Roman cities in order to build up the identity of the Christian communities. The same process is evident in imaging.

It should be mentioned here that Byzantium art cannot be separated from the historical background when basileia ton Rhomaion was transformed to Byzantium and its Greek roots (Evans 2004:15). In 1557 the name of the empire was replaced with the term Byzantium. Constantinople was seen as the place for the restoration of political and religious power (Evans 2004:5) (Figure 1).

The attempt to guard against pagan influences was predominant in the history of Christianity. It even led to theories that there is a close connection between the Isis cult and the development of private home altars (Weitzman 1982:5). It was believed that Serapis, with his shrine situated in Alexandria, united in himself the underworld powers of Osiris with the healing powers of Asclepius. His head was given the broad brow and copious hair of Jupiter. He wore a wreath of laurel and balanced a grain measure on his head. In $400 \mathrm{AD}$ an association between Serapis and Zeus developed (Mathews 1993:184-185).

What should be reckoned with in iconography is that Byzantium icons represent a wedding of the pagan icon genre $^{21}$ to Roman secular portraiture. ${ }^{22}$ Mathews (1998:51) refers to the case of Bishop Gennadios of Constantinople (458-457 AD) and a painter, who dared to paint the saviour in the likeness of Zeus. The story goes that he found his hand withered. The bishop healed him and instructed that Christ must have more short frizzy hair. However, in the later development of icons, the Zeus type won because within the framework of the power issues ${ }^{23}$ in Byzantium culture, the Zeus depiction was more forceful (Mathews 1998:51). ${ }^{24}$ The great male gods of antiquity - Asklepios, Serapis and even Suchos - 'all assumed the broad forehead, long hair, and full beard that characterized Zeus, the father of the gods. Christ should hardly be seen as less powerful than they' (Mathews 1998:51). ${ }^{25}$ In this regard the blessing Christ

21.Velmans points out the influence of Greek thinking on the idealism of the early church fathers (Velmans 2007:20), very specifically the impact of Pseudo-Dionysius church fathers (Velmans 2007:20), very specif
Areopagita (5 AD). See also Schaper 2014.

22.Many of the pagan images were Christianised in order to serve a different purpose. See for example: On a statue of Dionysus was written just above the genitals, Psalm 28:3 (8-9 AD) (Zakssaya 2006:50)

23.For further impact of power images in Byzantium icons, see the research of Helen Evans (2004:5-16).

24.Early Christian art is permeated with symbolism. See in this regard the very early testimony of Eusebius concerning Orpheus as symbol of Christ, even Heracles. All act as bearers of the idea of salvation, of the victory of good over evil, of prosperity and well-being (Zakssaya 2006:49).

25.Christian's claims of historical authenticity for the icons are founded on faith more than fact. Icons in Christian traditions should therefore not be interpreted from the viewpoint of historical fact but from the viewpoint of spiritual experiences and faithful imaging. Byzantium art was indeed an attempt to portray Christ as faithful imaging. Byzantium art was indeed an attempt to portray Christ as
superhuman, thus the reason for depictions larger than life scale (Mathews superhuman,
1998:51-52). 
from the monastery of St. Catherine on Mount Sinai should be rendered as a perfect example. 'All the verist tricks of Roman portraiture are added to convey the powerful presence of Christ' (Mathews 1998:51).

One can understand that iconography in the early Christian church cannot be understood without taking the Roman cultural background into consideration. Icons portraying the Christian understanding of the Divine were interlarded with notions of power and empire.

One should bear in mind that iconography in the Christian tradition was greatly influenced by the Roman culture of the period 200-400 AD:

The Romans were a matter-of-fact people, and cared less for fancy goods. Yet their pictorial methods of telling the deeds of the hero proved of great value to the religious which came into contact with their far-flung empire. (Gombrich 2006:96)

In her book Ikonographie und Ikonologie, Gabriele KoppSchmidt (2004:68-69) points out that it was during the fourth century $\mathrm{AD}$ that the Christianisation of Roman culture occurred. The Romans made use of examples from ancient Rome in their depiction of Christ and in their church architecture. Constantine and his family supported the 'new movement'. When Christianity became a state religion at the end of the fourth century AD, elements of the Caesar-cult were accommodated in the liturgy and priesthood. In order to gain power, it was for the clergy important to portray Christ in all images as a heavenly ruler and monarch, even to project the image of a pantokrator God rather than a compassionate and vulnerable, suffering God (theopaschitic paradigm).

A 'suffering God' is actually too 'ugly' and humiliating to function within the imperialistic paradigm of great power and expansionism. Pathos is more a human affect within vulnerable bodies than a divine characteristic in all-powerful Godhead. In fact, Christian thinking operated most of times with the schism between the spiritual realm and the cosmic realm, the dualism between perfection and imperfection, soul and body.

\section{Anthropomorphic speech: Seeing though the eyes of an embodied soul}

It was Michelangelo, in his struggle with his own agony and ecstasy, who turned to classic beauty in order to find 'spiritual peace' and to strive for contentment in life. His art was resisted by the Pope and the doctrinal stance of the clergy because faith could not make space for the beauty of the naked human body. The image of a body without clothes was perceived as disturbing ugliness rather than uplifting beauty. In the eyes of human beings, it stirred up notions of sin, guilt and shame rather than devotion, admiration and visionary hope. In Classical art the nude represents nobility and wisdom as the highest expression of human dignity.
Through stone and marble the striving of the classical artist was to probe into the transcendent realm of divine perfect shape by means of the human figure. For the ancient Greek viewer, the marble sculpture has not been a dead slab of marble, but a living being. The everyday world was imbued with the sacred. It was absolutely normal if you lived in ancient Greece to think of life as a container of spiritual forces. The sculpture actually constructed the identity of the Greek aristocratic class: the very form and appearance of these sculptures came to embody aristocratic values and selfidentity. The aristocratic class embodied the sacred in their self-representation and mobilised it on behalf of the community (Erez 2012:3) (Figure 2).

Youthful strength and vigour, grace and splendour of appearance became qualities sculpted into the form of deities by the Greek craftsmen because they were conceived of as signs of divine favour. The shape of the human body served to reinforce commitment to an elite self-identity while engendering a feeling of awe.

In Western Christian thinking and doctrine, the human body and naked figured became closely connected to the shadow side of life. In doctrine we have placed an enormous emphasis on justification and the notion of human beings as sinners. We have also placed an enormous emphasis on a human being as worker (Luther and Marx) and a human being as thinker (Aquinas, Descartes and orthodox doctrine). We sanctified the mind as the faculty of soulfulness, which excluded and was deprived of any form of corporeality. Our celebrative and imaginative faculties have atrophied (Cox 1969:11).

One can even add: our aesthetic and imaginative faculties have become mummified under the pressure of the perceived sinfulness of embodiment. The body is dirty and the soul is pure. Such a view resulted in the emphasis in preaching: life and bodily experiences are less 'spiritual'. Due to human

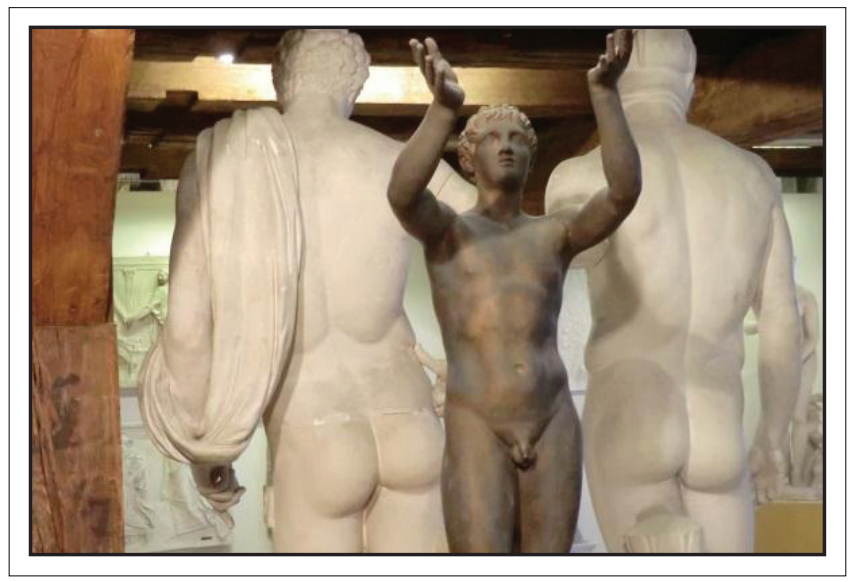

The sculptures are all in the Classical style of ancient Greece. They present a kind of aesthetics that transcends the boundaries of human wickedness, slavery and suffering. The figures represent rhythm, grace, uplifting beauty and dynamic harmony. A group of casts in the Royal Cast Collection, Copenhagen. The front figure is called: Youth with lifted arms. Found 1503, Greece 4 BC. Photos by D. J. Louw. Permission from museum.

FIGURE 2: Youth with lifted arms. 
sinfulness the kerygmatic dimension in preaching focused more on moral than aesthetic issues.

We should now pose the challenging question: is it possible in preaching to proclaim the ugly figure of a deformed suffering Son of God as an embodiment of divine aesthetics?

Can the Pauline notion of 'preaching a weak and crucified God' and the icon of divine vulnerability provide a paradigmatic framework for poetic communication in homiletics?

\section{Towards a Pauline paradigm for aesthetic preaching: The weakness and ugliness of God}

The Confession of Faith (Belgic Confession 1959) starts with the notion of power as the creation, preservation and government of the universe. God as Father:

watches over us with paternal care, keeping all creatures so under his power that not a hair of our head (for they are all numbered), nor a sparrow can fall to the ground without the will of our Father ... (and not one of them falls apart from your father's will) (Belgic Confession 1959)

Although 'will' is not mentioned in the Greek text (Mt 10:29; literally: without our Father), the interpreters read 'will of the father' into the text. In the background of the religious mind, God determines everything in a cause-and-effect manner so that the will of God should at least equal divine power. Divine power is then interpreted in terms of cause (first principle) and governance (strength) and not in terms of care and compassion (vulnerability).

The point is: strong and powerful people need strong and powerful deities (Hall 1993:108).

If gods become 'weak', religions seem to fail and lose their influential power. One could even toy with the idea that the decline of religions and their gods is closely related to the bankruptcy of their images and the appearance of a more forceful set of divine images. 'As with politicians, nothing is more important to gods than image. If a god's image should fail, how long could he survive?' (Mathews 1993:10). When one applies this statement of Mathews to the topic of iconography and my research on the interplay between Godimage, human suffering and the quest for meaning, the assumption of Mathews is quite appealing, namely that the secret of the longevity of the God of Israel is perhaps the fact that Yahweh never allowed an image of himself:

A god who appeared weak, a god who was seen to stumble when facing off with another divinity or who looked on helplessly while his image was defaced and dismembered, could never again expect a sea of heads bowed in worship before him. He must perforce follow the fate of his image. (Mathews 1993:10)

However, my hunch and hypothesis is that in the 21st century, due to an intensified awareness of human suffering and vulnerability, issues of injustice, discrimination and stigmatisation, the notion of a weak and vulnerable God (compassionate intimacy), as well as the theopaschitic concept of a suffering God, could provide appropriate images to convey the meaning of the Christian faith by means of 'passionate preaching'.

In the history of the church, the Christian establishment was deeply influenced by a religion designed to serve the purposes of empires. Influenced by Constantine imperialism, theology exploited the power potential of the Christian God and ran into the danger of minimising everything reminiscent of divine vulnerability and self-emptying. It was indeed difficult for early Christianity to maintain that Christ is Lord, when the image of Jupiter and the statues of Hercules were still dominant in the association and minds of people.

Without any doubt, culture frames the context of Godimages.

The 'Father Almighty' developed under the influence of an affluent society into the romantic sentimentality of Father Christmas All-merciful. Instead of a suffering God, the triumphalism of a theology of glory 'removed the cross from the heart of God' (Hall 1993:96):

God is depicted as one who, unlike us, does not exist under the threat of nonbeing in any of its manifestations. Thus, the divine power (omnipotence) is not challenged by any lack or weakness; the divine knowledge (omniscience) is not circumscribed by ignorance, uncertainty, or inherent limitation; the divine presence (omnipresence) is not subject to the constraints of time and space; and God is not vulnerable to change or prey to passions that may be aroused by any existential eventuality (immutability). (pp. 96-97)

Mostly it is our understanding of power in politics and the social sphere that dominated both our understanding of God and the meaning of our being human. Our common use of power takes political power as its exemplar, power as domination. The perfection or fulfilment of power as domination easily becomes manifest as 'absolute power', 'the tyrannical enslavement or eradication of whatever opposes such power' (Pasewark 1993:3). When projected on to 'God Almighty', God appears as the invincible tyrant or judgemental judge. The whole of the Christian life and the realm of religion are then framed by a rule-governed supervision of action as prescribed by ethics and the iron will of God. There is then virtually no space for ethos, a purposeful end (telos), ${ }^{26}$ the aesthetics of life, the aesthetics of existence, the beauty of creation. As a prescriptive rule (legalism) ethics dominated ethos, 'correct truth' (positivism) supersedes aesthetics.

Very surprisingly, over against the power of defensive faith, Paul comes up with a startling thesis that is contrary to the powers that reside in theology and the church (Caputo 2007:62): vulnerable faith and the weakness of God (to preach the notion of the crucified God: theologia crucis). Vulnerability and weakness suddenly became powerful categories. Within

26. For the connection between telos and aesthetics, see Pasewark (1993:36). 'The.... is a telos, an end, toward which the ethical life orients itself. To be sure, it may be an aesthetic telos rather than a rule-governed supervision of action, but the ethical an aesthetic telos rather than a rule-governed supervision of action, but the ethical
life is not devoid of meaning. The project of 'aesthetics of existence' is, in fact, a project of meaning creation'. 


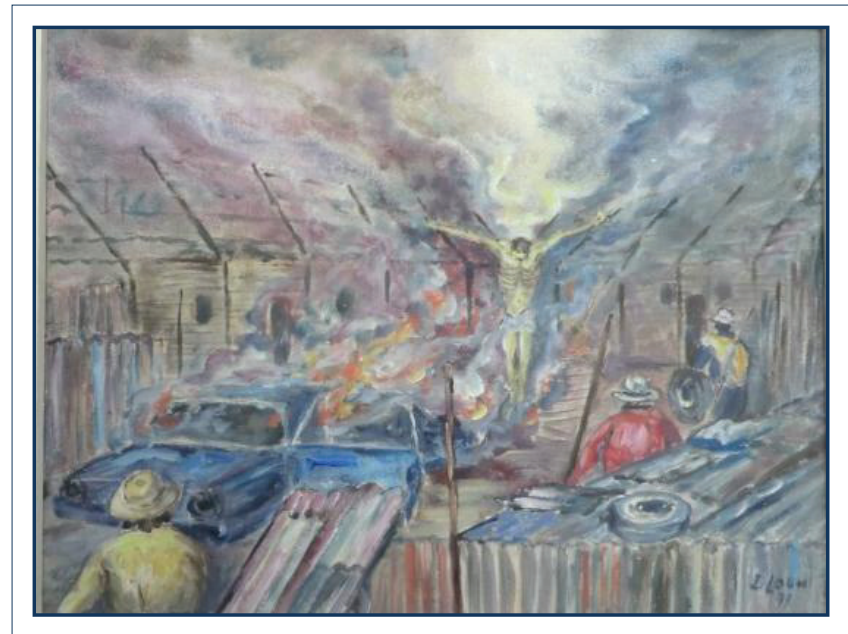

The painting can be called: Cross-roads Cape Flats. Crossroads is also the name of a huge squatter camp in the Cape Flats. During the time of the struggle against apartheid God was rendered as present through the Cross within the cross (suffering) of oppressed people. The painting depicts divine tragedy within a paradox: My God, my God why hast thou forsaken $m e$ ? In the forsakenness the divine presence is established in a paradoxical mode. Forsakenness gives a glimpse of the sublime in life (a township crucifixion, an icon of the suffering God within the realm of oppression, D. J. Louw [1991]).

FIGURE 3: Crossroads, Cape Flats (Township Crucifixion). ${ }^{27}$ The necklaced Christ as victim of the Roman soldiers (Apartheid policy makers) within the hell of township life (Louw 1991). In the painting the dying Son of God was killed by the injustice of all forms of oppressive imperialism.

the power or charisma of the Spirit, they are designed for the empowerment of human beings deprived of dignity and 'beauty' because of the ugliness of inhumane stigmatisation and discrimination.

Paul links God to the event of suffering and introduces the 'weakness of God'; the logos of the cross (logos tou staurou). This notion of power is marked as 'foolishness' (a variant of the aesthetic category of ugliness) for 'imperialistic preaching'.

The power of human beings (ousia) is challenged by the 'weakness of God' which is stronger than human strength (1 Cor 1:25). Why? Because it affirms God's identification with the vulnerability of suffering human beings. It opposes destructive domination and affirms constructive opposition. God becomes the helpless innocent victim of the Roman soldiers. The sacredness and divinity reside in the cry of protest: 'My God, My God why have you forsaken me?' With the act of forgiveness, Jesus as the icon (eikon) of God, not of Roman power, became an innocent and helpless victim of Roman imperialism (Figure 3).

Crossroads, Cape Flats (Township Crucifixion). ${ }^{27}$ The necklaced Christ as victim of the Roman soldiers (Apartheid policy makers)

27.Crossroads' is the name of a squatter camp in the Cape Flats. During the time of the struggle against apartheid, it became a very violent setting. People were even necklaced if it seemed that they were not supporting the violent option against apartheid

At that time, I felt guilty for not being involved directly in the struggle. I was confused and felt uncertain about being a professor at an institution that to a large extent played a vital role in the formulation and theological justification of apartheid in the beginning of the 1950s. I considered the option to resign and felt that I had no legitimacy, even no authority at all to teach or to preach In my confusion and personal agony I decided to use art as a medium to express my confusion and personal agony, I decided to use art as a medium to express my deepest and sincere attitude. Painting became a vehicle to articulate a viewpoin and stance in life which I could not explain in words. Even the attempt to preach on the injustice of apartheid and the fact that it could be labelled as a heresy was doomed to failure and seemed to me illegitimate. I thought that if I express $\mathrm{m}$ feelings through a painting, the visual portrayal could gain afterwards an objectivity and integrity that could not be achieved by preaching, teaching or verbalising, thus
the option for an aesthetic expression.

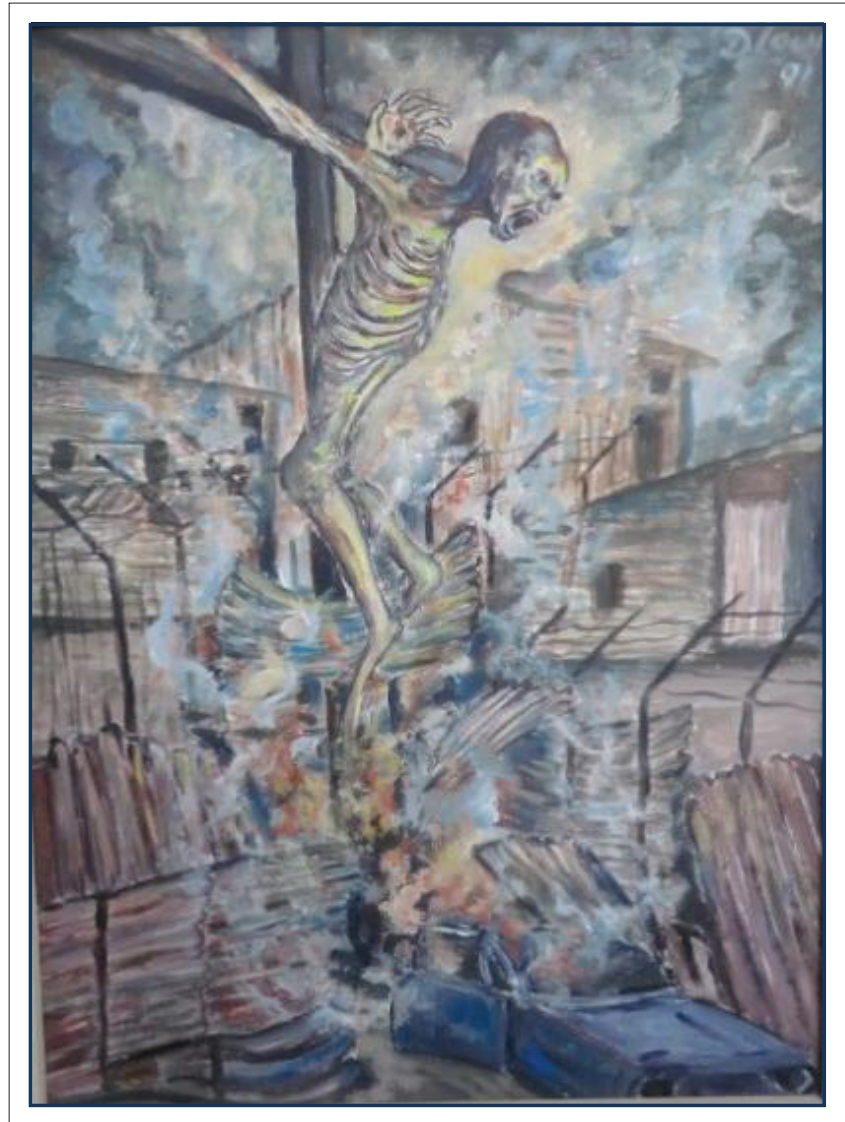

The painting can be called: Cross-roads Cape Flats. Crossroads is also the name of a huge squatter camp in the Cape Flats. During the time of the struggle against apartheid God was rendered as present through the Cross within the cross (suffering) of oppressed people. The painting depicts divine tra painting depicts divine tragedy within a paradox: My God, my God why hast do forsaken me? a glimpse of the sublime in life. A township crucifixion; an icon of the suffering God within a glimpse of the sublime in life. A township
the realm of oppression. D. J. Louw (1991).

FIGURE 4: Cross-roads Cape Flats.

within the hell of township life (Louw 1991). In the painting the dying Son of God was killed by the injustice of all forms of oppressive imperialism.

According to Paul's understanding of preaching the crucified Christ, foolishness reframes God into 'beauty' by means of shear ugliness (Figure 4):

God is not a cosmic force, a worldly power, a physical or metaphysical energy or power source that supplies energy to the world, who designs it, starts it up and keeps it going, and who occasionally intervenes here and there with strategic course corrections, a tsunami averted here, a cancerous tumour there, a bloody war quieted over there. (Caputo 2007:65)

As Caputo argues, we should replace Christian icons of amor fati, fatalism, with Christian icons of amor venturi, a love of unconditional acceptance; love as a challenging venture with God, our covenantal Partner for Life as proofed by anguish and forsakenness (derelictio). The forsakenness of Christ opens up a whole new perspective and angle on seeing the unseen.

\section{(footnote 27 continues...)}

To my mind, the whole series on 'Crossroads' should be viewed as a different kind of 'preaching'. Due to their symbolic value, they should be viewed as icons regarding the engagement of God with the suffering in squatter camps. 
In seeing the unseen, the unseen is found to be embedded in ambivalence and paradox. Sometimes, in order to understand the truth better, a comic twisting was necessary, hence the notion of parody. However, even within 'funny twisting', the irrational images of surrealistic icons reveal the realm of the deep-seated schisms in life. Paradox and parody in icons thus become vehicles for the articulation of existential turmoil and the ambivalences of life, i.e. the struggle to come to terms with the unavoidable scars of life. In this regard folly even reveals the divine, painful smile of a transcendent parody of the suffering of human beings.

Dalí's encounter with Father Bruno de Jésus-Marie, a French Carmelite monk and authority on Catholic mysticism, helped him to discover a cosmic spiritualism. Father Bruno de Jésus-Marie discussed with Dalí the life and work of the sixteenth-century Spanish Mystic Saint John of the Cross (1542-1591). He showed him a reproduction of an original drawing of Christ on the cross by the saint's own hand (Wallis 2008:38). This encounter with spiritual mysticism helped Dalí to combine his previous 'Profane Self' with a new 'Sacred Self' (Wallis 2008:38). Dalí identified specifically with Saint John of the Cross as a fellow artist-mystic and concluded that his own "saintly" mission was the "divine rescue of painting from its imprisonment in the "blasphemous" aesthetic of modern art. Thus, both in his mind and in the visual realm of his works of art, he was not simple the Spanish artist Salvador Dalí, but rather the Spanish mystic and saviour Saint Dalí' (Wallis 2008:38). The Christ of Saint John of the cross served as a 'visual manifesto for Dali's new mystical mission and religious devotion' (Wallis 2008:39).

In 1950 Dalí had his 'cosmic dream'. On reflection he understood that Christ and his cross can bring about a cosmic integration of life and meaning. In 1951 he painted Christ of Saint John of the Cross. It was the 'ecstasy of God' (Wallis 2008:37) who 'saved' Dalí, in order to become 'the saviour' of art. Through cosmic mysticism Dalí found a new calling, destiny and responsibility, namely of saving modern painting from its degenerate, blasphemous aesthetic (Figure 5).

It becomes clear how the funny twisting and delusionary distortion of surrealism can help one to 'see' differently. Surrealism operates at the sharp edge of contradiction. The tension created by paradox and ambivalence creates new icon visions and aesthetic freedom. 'To treat ambivalence with humour is to keep it loose; humour oils the joint where contradictions meet. If humour evaporates, then ambiguity becomes polarized and conflict follows' (Hyde 1998:274) (see Figure 6).

\section{Conclusion}

With preaching as art is meant the attempt to merge form with content and essence of the Christian faith in order to assist iconic viewing in its attempt to designate and signify

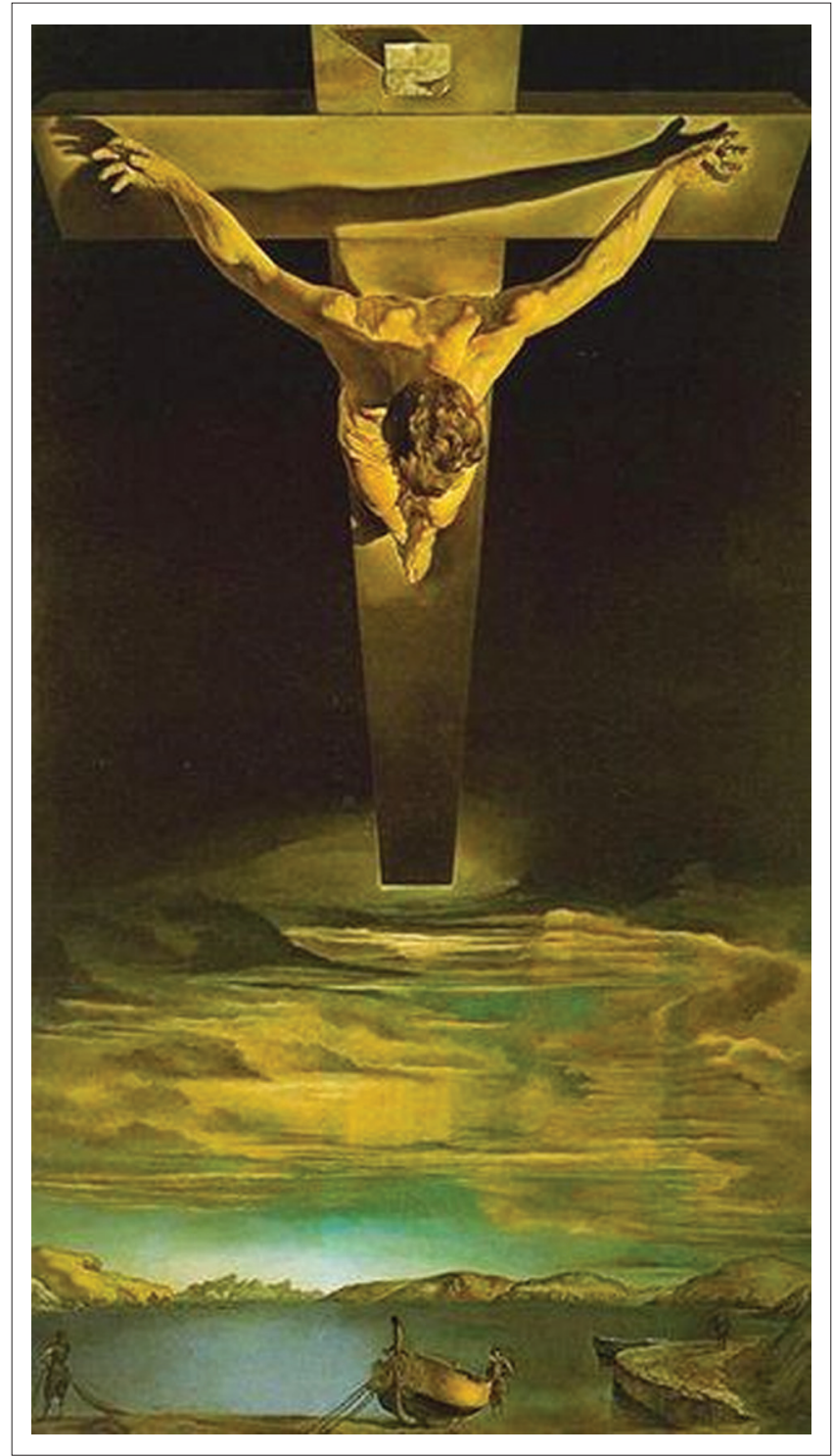

Due to his cosmic mysticism and paranoiac, surrealistic vision, Salvador Dalí painted 'Christ of St John of the Cross' (1951). Kelvingrove Art Gallery and Museum is a museum and art gallery in Glasgow, Scotland (http://en.wikipedia.org/wiki/Christ_of_Saint_John_of_the_ Cross).

FIGURE 5: Christ of Saint John of the Cross.

images of God in terms of religious thinking (binding together, religare). Preaching is thus involved in the struggle to integrate life within the realm of human suffering, destruction, violence and death. Death is the stage and pulpit of serious preaching.

Preaching should move from the cathedral to the market place in order to heal life.

In order to undergo a paradigm switch, from static omnicategories that uphold an imperialistic ecclesiology and impassable theology (immutable and omnipotent God), to an aesthetics of compassion, practical theological reflection should guide and direct homiletics into a theology of the intestines (bowel categories). ${ }^{28}$ The challenge to a practical

28.In the New Testament the mercy of God is often described in bowel categories, namely ta splanchna (splanchnizomai $=$ movement and pain within the bowels). A good example of comfort as linked to a theology of the intestines is $L k$ 15:20. When 


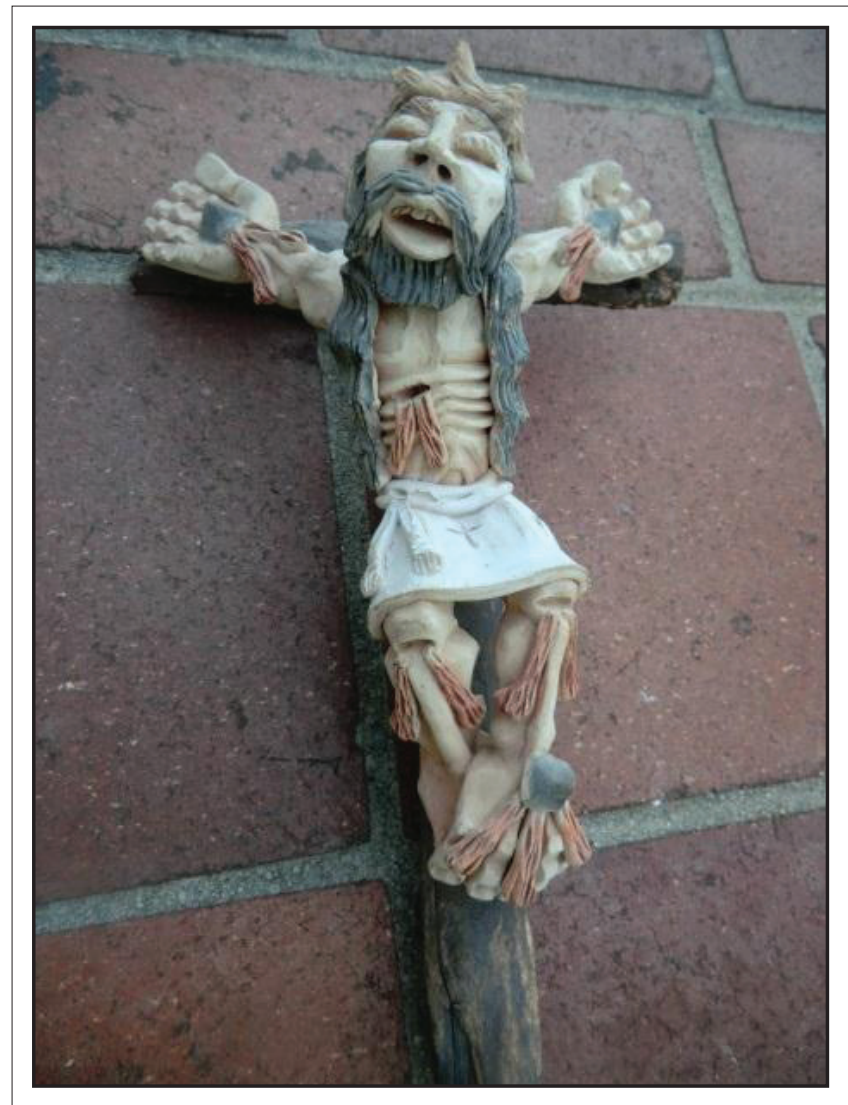

I bought this ceramic crucifixion in a small shop in Cusco Peru (unknown artist). It represents an Inca interpretation of the suffering of Christ. To my mind it is an excellent depiction of total pain and forsakenness. Within parody one can even interpret the painfu cry of forsakenness, derelictio, as the anguish of God as an expression of Divine Laughter: cry of forsakenness, derelictio, as the anguish of God, as an expression of Divine Laughter: for a fow moments arody forsakenness, Divine truth is revealed as paradox: the weakness of God is the powe
(strength) of God.

FIGURE 6: Ceramic crucifixion.

theology of life is to move from attempts to keep God going (theological maintenance) into healing and helping thinking, namely a leitourgia and diakonia of life that tries to keep human beings going (humanising life). Rather than the omnipotence of God, Jawhe categories points into the direction of infiniscience categories (God-images in terms of the verb to be: I shall be your God).

In this regard, one should maintain the following homiletical assumption in an aesthetics of communicative preaching: the mediation of words operates within the connections between form (eidos; essence, meaning) and matter (hýle; ontic dimension).

Art as homiletics is about the search for symbols and metaphors that make it possible for acts of believing and religious experiences to start seeing and imaging the unseen in such a way that meaning is disclosed, hope is instilled and human dignity is promoted, thus the option for the passio Dei as image for iconic preaching within the discrepancies, paradoxes and painful trajectories of life. The paradigm and God-image behind theopaschitic preaching is the aesthetic category of the 'ugliness of God'.

(footnote 28 continues....)

the father saw his prodigal son, he was moved with pity and tenderness. To splanchna displays the unconditional love and mercy of a caring father; it is essentially a component of the father's being functions.

\section{Acknowledgements Competing interests}

The author declares that he has no financial or personal relationships which may have inappropriately influenced him in writing this article.

\section{References}

Belgic Confession, 1959, Psalter hymnal. Doctrinal standards and liturgy of the Christian Reformed Church, Publication Committee of the Christian Reformed Church, Inc. Publishers, Grand Rapids, MI.

Berger, J., 1972, Ways of seeing, British broadcasting Corporation, Penguin Books, London.

Berkhof, H., 1973, Christelijk geloof, Callenbach, Nijkerk.

Billgren, E., 2011, What is art? And 100 other very important questions, Bokförlaget Langenskiöld, Stockholm.

Blumenthal, K., 2012, Steve Jobs. The man who thought different, Bloomsbury, London.

Campbell, L. \& Cilliers, J.H., 2012, Preaching fools. The Gospel as a rhetoric folly, Baylor University Press, Waco, TX.

Caputo, J.D., 2007, 'Spectral hermeneutics. On the weakness of God and the theology of the event', in J.D. Caputo \& G. Vattimo (eds.), After the death of God, pp. 47-85, Columbia Press, New York.

Cobb, M., Puchalski, C.M. \& Rumbold, B., 2012, Oxford textbook of spirituality in healthcare, Oxford University Press, Oxford, pp. vii-viii.

Cox, H., 1969, The feast of fools. A theological essay on festivity and fantasy, Harper \& Row Publishers, New York.

Dahlgrün, C., 2009, Christliche Spiritualität. Formen und Traditionene der Suche nach Gott, De Gruyter, Berlin.

Dissanyake, E., 1992, Homo aestheticus: Where art comes from and why, Free Press, New York.

Dworkin, R., 2013, Religion without God, Harvard University Press, London.

Erez, E., 2012, And man created man: Construction of the body and gender identity in classical sculpture. Booklet to accompany a visit of the royal cast collection, Yale University, Copenhagen.

Evans, H., 2004, 'Faith and power 1261-1557', in H.C. Evans (ed.), Byzantium. Faith and power, Metropolitan Museum of Art, New York.

Gombrich, E.H., 2006, The story of art, Phaidon Press, London.

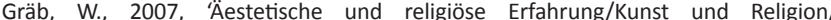
Produktionsäesthetik/Receptionsäestethik', in W. Gräb \& B. Weyl (hrsg.), Handbuch Praktische Theologie, pp. 737-747, Gütersloher Verlagshaus, Gütersloh.

Gräb, W., 2012, 'Kunst - die ansprechende Sprache der Religion', in T. Erne \& P. Schütz (hrsg.), Der religiöse Charme der Kunst, pp. 53-67, Ferdinand Schöningh, Paderborn.

Gräb, W., 2013, Predightlehre. Über religiöse Rede, Vandenhoeck \& Ruprecht, Göttingen.

Grethlein, C., 2012, Praktische Theologie, De Gruyter, Berlin.

Hall, D.J., 1993, Professing the faith. Christian theology in a North American context, Fortress Press, Minneapolis, MN.

Harland, P.A., 2009, Dynamics of identity in the world of the early Christians, T\&T Clark, New York.

Hermelink, J. \& Deeg, A., 1989, 'Preface', in J. Hermelink \& A. Deeg (eds.), Viva Vox Evangelii - Reforming preaching. Studia Homiletica 9, pp. 5-6, Evangelische Verlagsanstalt, Leipzig.

Hoeps, R., 2012, 'Bildtheologie jenseits der Inhaltsdeutung. Zwischen christliche Bildkonzepten und Kunst der Moderne', in T. Erne \& P. Schütz (hrsg.), Der religiöse Charme der Kunst, pp. 89-106, Ferdinand Schöningh, Paderborn.

Hyde, L., 1998, Trickster makes this world. Mischief, myth, and art, North Point Press, New York.

Inbody, T., 1997, The transforming God: An interpretation of suffering and evil, Westminister, Louisville, KY.

Jaspers, K., 1932, Philosophie, Dritter Band. Metaphysik, Verlag von Julius Spinger, Berlin.

Jaspers, K., 1962, Der Philosophische Glaube angesichts der Offenbarung, Piper Verlag, München.

Käfer, A., 2015, 'Gottes Allmacht und die Frage nach dem Wunder. Ein Beitrag zum Vergleich der Positionen Friedrich Schleiermachers und Karl Barths', in M Gockel \& M. Leiner (hrsg.), Karl Barth und Friedreich Schleiermacher. Zur Neubestimmung ihres Verhältnisses, Vandenhoeck \& Ruprecht, Göttingen.

Kopp-Schmidt, G., 2004, Ikonograpahie und Ikonologie. Eine Einführung, DeubnerVerlag für Kunst, Köln.

Korsch, D., 2011, 'Life science - gelebte Religion - Theologie als Lebenswissenschaft', in T. Klie, M. Kumlehn, R. Kunz \& T. Schlag (hrsg.), Lebenswissenchaft Praktische Theologie?! Praktische Theologie im Wissenschaftsdiskurs, pp. 341-344, Band 9 , de Gruyter, Berlin. 
Kumlehn, M., 2011, 'Einleitung: Praktische Theologie als Lebenswissenschaft?!', in T. Klie, M. Kumlehn, R. Kunz \& T. Schlag (hrsg.), Lebenswissenchaft Praktische
Theologie?! Praktische Theologie im Wissenschaftsdiskurs, pp. 1-8, Band 9, de Theologie?! Prakter, Berlin.

Lauster, J., 2007, 'Leben. Genetischer Code/Lebensphilosophie/inneres Leben/ewiges Leben', in W. Gräb \& B. Weyl (hrsg.), Handbuch Praktische Theologie, pp. 137-148, Gütersloher Verlagshaus, Gütersloh.

Long, T., 1989, The witness of preaching, Westminster, Louisville, KY.

Louw, D.J., 2008, Cura vitae. Illness and the healing of life, Lux Verbi, Wellington.

Louw, D.J., 2014, Icons. Imaging the unseen. On beauty and healing of life, body and soul, Sun Media, Stellenbosch.

Mathews, T.F., 1993, The clash of Gods. A reinterpretation of early Christian art, Princeton University Press, Princeton, NJ.

Mathews, T.F., 1998, Byzantium. From antiquity to the renaissance, Yale University Press, New Haven, CT.

Moltmann, J., 1972, Der gekreuzigte Gott, Kaiser, München.

Nyssen, W., 1982, 'Die theologische und liturgische Bedeutung der Ikonen', in K. Weitzman et al., (eds.), Die Ikonenen, pp. 413-416, Herder Verlag, Freiburg im Breisgau.

Nouwen, H.J.M., 1979, The wounded healer, Ministry in Contemporary Society, Doubleday, Garden City, NY

Pasewark, K.A., 1993, A theology of power. Being beyond domination, Fortress Press, Minneapolis, MN.

Pellegrino, E.D., 2012, 'Foreword', in M. Cobb, C.M. Puchalski \& B. Rumbold (eds.) Oxford textbook of spirituality in healthcare, p. vi, Oxford University Press, Oxford.
Puchalski, C.M. \& Ferrell, B., 2010, Making health care whole. Integrating spirituality into patient care, Templeton Press, West Conshohocken.

Rebentisch, J., 2013, Theorien der Gegenwartskunst. Zur Einführung, Junius Verlag, Hamburg.

Schaper, M., 2014, 'Editorial', in Die Kunst der Antike, p. 1, Geo Epoche Edition Nr. 9-01/2014.

Schröder, R., 2009, Abschaffung der Relgion? Wissenschaftlicher Fanatismus und die Folgen, Herder, Freiburg.

Seel, M., 2012, 'Transzendenzen der Kunst', in T. Erne \& P. Schütz (hrsg.), Der religiöse Charme der Kunst, pp. 37-51, Ferdinand Schöningh, Paderborn.

Steinmeyer, A.M., 2011, 'Ikonische Innovationen. Überlegungen zur Predigt im Horizont kultureller Lebenswelt', in T. Klie, M. Kumlehn, R. Kunz \& T. Schlag (hrsg.), Lebenswissenchaft Praktische Theologie?! Praktische Theologie im Wissenschaftsdiskurs, Band 9, pp. 253-270, de Gruyter, Berlin.

Van de Beek, A., 1984, Waarom? Over lijden, schuld en God, Callenbach, Nijkerk.

Velmans, T., 2007, Byzanz. Kunst und Architektur, Michael Imhof Verlag, Petersberg.

Wallis, J., 2008, 'Holy Toledo! Saint John of the Cross, Paranoiac-Mysticism, and the Life and Work of Saint Dali', in M.R. Taylor (ed.), The Dalí renaissance. New perspectives on his life and art after 1940, pp. 37-52, Yale University Press, New Haven, CT.

Willikens, B. \& Schütz, P., 2012, 'Auf der Suche nach dem religiösen Charme der Kunst', in T. Erne \& P. Schütz (hrsg.), Der religiöse Charme der Kunst, pp. 255-273, Ferdinand Schöningh, Paderborn.

Young, D. \& Young, M., 2005, The art of the Japanese garden, Tuttle Publishing, Tokyo.

Zakssaya, V., 2006, 'The classical heritage in Byzantine art', in The road to Byzantium. Luxury arts of antiquity, pp. 49-57, Fontana (Somerset House), London. 